\title{
Geometric Mosaics of Baetica
}

\section{Baetica'daki Geometrik Mozaikler}

Sebastián VARGAS VÁZQUEZ*

(Received 13 February 2017, accepted after revision 01 June 2017)

\begin{abstract}
With the present research we present a preview of an ambitious investigative project currently being carried out that pursues the study and analysis of all the geometric mosaics of Roman Baetica, most especially their composition and/or geometric design. Additionally, we offer a general view of the investigative course of action, the method, and the technique among other things, and an overview of the obtained results up to this point. The sheer quantity of floor mosaics obtained from within the territorial borders of ancient roman Baetica and the complexity of this assignment due to the utilized methodology make it so that our research advances rather slowly. Even so, we currently have more than half of the mosaics of Baetica catalogued and analyzed. The study's progress and a rather large portion of the catalogue of geometric designs have been recently published and are available at: Vargas Vázquez, 2014, íd. 2016.

Throughout this research we hope to demonstrate the importance of the mosaic in the roman province of Baetica as a highly prized and demanded element, in both urban and rural environments. We seek to highlight the geometry of the mosaic expressed in its various and interesting forms, designs and/or compositions that are both simple and complex, and in many cases fruit of a marketed and evident creativity, singularity, and originality.
\end{abstract}

Keywords: Baetica, geometric mosaic, geometric design, composition, tesserae.

\section{Öz}

Bu çalışmada, Roma Dönemi kenti Baetica’da bulunan tüm geometrik mozaiklerin, özellikle bunların kompozisyonunun ve geometrik tasarımının incelenmesini ve araştırılmasını yürütmekte olan iddialı bir araştırma projesinin önizlemesi sunulmaktadır. Bunlara ek olarak, bu araştırmanın eylem planı, metodu ve tekniği açılanacak olup, şimdiye değin elde edilen sonuçlarla ilgili genel bir çerçeve çizilecektir. Roma Dönemi Baetica kentinin bölgesel sınırları içerisinde tespit edilen mozaiklerin sayıca çok olması ve uygulanan metodoloji nedeniyle, bu araştırma konusunun giriftliğinden kaynaklanan sebepler nedeniyle çalışma yavaş bir biçimde ilerleme kaydetmektedir. Yine de, Baetica'da yer alan mozaiklerin yarısından çoğu kataloglanmış ve analiz edilmiştir. Çalışmanın bulunduğu aşama ve çoğunluğu geometrik desenlerden oluşan mozaiklerin kataloğu yakın zamanda yayınlanmıştır (bknz. Vargas Vázquez, 2014, íd. 2016).

Bu çalışmada, Baetica'nın hem kursal hem de kentsel alanlarında yer alan, oldukça de ğerli ve talep edilen bir öğe olan Roma Dönemi mozaiklerinin önemi vurgulanacaktır. Bunun yanı sira, çeşitli ve ilginç formlardaki mozaikler, hem basit hem de karmaşık olarak yapılmış tasarımlar velveya kompoziyonlar, pek çok durumda pazarlanmış olan belirgin bir yaratıcılık, bireysellik ve orijinallik gibi konular aydınlı̆̆a kavuşturulmaya çalışılacaktır.

Anahtar Kelimeler: Baetica, geometrik mozaik, geometrik tasarım, kompozisyon, tesserae.

The Roman Baetica is divided administratively into four conventus iuridici: Cordubensis, Gaditanus, Hispalensis and Astigutanus, whose capitals were Corduba, Gades, Hispalis and Astigi. These had similar limits to Andalusia at present although not absolutely exact, because in it there was an important part of South Badajoz too. In addition, some areas of Granada, Jaén and Almería were also outside of this territory. It is certain, in the present state of the investigation that these limits are not as clear as we hoped.

\footnotetext{
* Sebastián Vargas Vázquez, Universidad de Sevilla, 4 San Fernando Str. Sevilla 41004, Spain. E-mail: svargas2@us.es
} 
In any case, it is an undeniable reality that the Baetica province was one of most prosperous and rich of The Roman world, due to its enormous economic potentiality and to its wealth derived from many frontiers. It also had to do with certain factors that allowed or made it possible for the increasing economic boom, such as the terrestrial and fluvial wealth, as well as communication channels and potentiality of its earth and waters. With them, agriculture, the cattle industry, mining, quarries, salt, salt conservatives, among others give origin to the birth of an important number of rustic and marine villas. Two products were the determining factors for their economic development in the height of boom of the villas and their decorative programs, especially with respect to the mosaics, oil and wine.

The production and marketing of two basic agricultural products, wine and oil, which together with cereals constituted the agricultural triad of the Mediterranean area; play in the Baetica a fundamental and prominent role for their economic development. Classic references speak about the wine of the Baetica with the dates extracted by archaeologists, it can be added to the numerous bunches and vineyards and Bacchic scenes represented in mosaics as evidence of farming and the significance of vineyards and wine in the Baetica (Vargas Vázquez - López Monteagudo in print). Bacchic scenes like these are extended around the South of the peninsular's geography, which are documented with a special and significant frequency in mosaics from Italica and Córdoba and, in a more reiterated way, in Écija. It can be added to other regions and they do not happen unnoticed in the Roman towns of Baetica, where they become a figurative element.

It is obvious, that there is a direct relationship between the Bacchic scenes and the production of wine or culture of the farming vine, mainly if it considers the mystical and religious characters that accompany this type of representation and the idea of the simple taste for this theme ${ }^{1}$. In the specific case of Écija it is necessary to add the circumstances of the multiple Bacchic representations that are exhibited in the mosaics and aren't reflected in others, at least with frequency (Vargas Vázquez - López Monteagudo in print).

The same, although to a lesser extent happens with oil, whose plants and allegorical figures are mainly in the mosaics of Córdoba and Écija, is directly related to the production and the export of oil. A subject that has been an objective of numerous and extensive bibliographies by $\mathrm{M}$. Ponsich and most recently by $\mathrm{J}$. Remesal. There isn't any doubt about the wealth generated by the Baetica commerce of olive oil, documented in the epigraphy on amphoras, detonated the splendor of these villas and their rich mosaics, a mirror of the prosperity of its proprietors (López Monteagudo 1998: 359-376; López Monteagudo 2007: 470472; Vargas Vázquez - López Monteagudo in print). The splendor was shown by the luxury and emblazonment, which domus and villas offered, where some proprietors will not repair, as they show the use, between many other elements of prestige, of marble, sculpture and mosaic, that sometimes, as it has been demonstrated in the Roman villa of the Station of Antequera, makes clear use of tesserae covered with affine and a delicate gold layer (Romero Pérez - Vargas Vázquez 2012: 823-828; Vargas Vázquez 2016: 18).

\footnotetext{
1 In spite of it, the continued use of Bacchic scenes, in Écija and Italica, and other zones of Baetica, it is a fact that is disquieting and invites to the reflection, mainly when some of them include episodes related to the realistic production of the wine, that is to say, the walking on the grape in lagar in mosaics of Italica and of the capital from Astigi. They lack, however, half mythological scenes, half realistic scenes, where appear erotes or putti collecting grapes in polychrome and $\mathrm{b} / \mathrm{w}$ mosaics of the capital of Lusitania.
} 
The mosaics of the Baetica are therefore the reflection of a widely demanded and consolidated urban product, which are the reflected scope of the wealth of their owners too, as archaeological sites, like Italica, Córdoba, Sevilla, Écija or Carmona among others. These mosaics are a reflection of a widely occupied, organized and well-structured field, where villas act as controllers, articulated and unifying elements of the territory, and where owners let glimpse their power and economic status with elements of prestige like mosaics, especially among third and fifth centuries AD. Although many scattered villas in the Andalusian territory throw earlier chronologies, being in another reality, surviving very extensive chronological arcs (Vargas Vázquez 2016: 318-319).

All this splendor derived from the urban and also rural world, lived by the Roman Baetica at different moments throughout the centuries, is partly responsible for the enormous catalogue of mosaics on which at the moment Andalusia counts. This extensive catalogue, however, does not have to suppose more than a minimal part of which it had to contain in its origin.

As mentioned at the beginning of this article, our investigation concentrates on the analysis of geometric mosaics in the Roman Baetica, especially with the compositions and/or geometrical designs that define these mosaics, and all the nourished and interesting volumes of pavements made up of more than 400 units $^{2}$. For its attainment, one of the essential sections is framed within an applied methodology of study, which indeed consists of the cataloguing of all the mosaics ${ }^{3}$, which is not an easy task due to the difficulties involved in many cases, access to information and some of the copies.

At the present state of investigation, our catalogue already counts the registry of the mosaics of deposits in Italica, Écija, Sevilla and Carmona, with a volume of more than 270 pavements. Next to these, other urban nuclei of Roman age mosaics have also been provided to our catalogue, though in smaller quantities emphasizing Ilipa Magna, Antikaria and Cartima. In the previous mentioned cases, their pavements are already a part of our catalogue of mosaics. The registry of Córdoba's mosaics, which was the capital of the province, prints a greater difficulty, and also counts on a huge number of mosaics. Many of these remain unpublished and in many cases they are stored in warehouses at the Archaeological Museum of Córdoba. The tracking of these archaeological excavations also demonstrate a great number of mosaics without studying and with difficult accessibility, one reason why the cataloguing of all of them appears to be difficult although not impossible. This, therefore, is one of the pending aims of our work.

Next to the mosaics derived from the urban nuclei of The Roman age, our research also goes after the analysis of villa pavements placed in the geographic limits of Baetica. We can assure in the present state of the investigation that all pavements derived from the villas of Baetica, discovered until 2015, are registered in our catalogue, forming a nourished group of more than 150 pavements, relocated in 44 different sites ${ }^{4}$.

2 There is not an enter, among others, the mosaics of Córdoba, city that surely is going to increase of ample way and important the catalogue of pavements that we are conforming.

3 Our catalogue has the capacity for any type of tessellated pavement, independently of its decoration and therefore not only the geometric mosaics, as well as any type of pavement, with the intention of securing a final image of the types of pavements that occurred in the Roman Baetica, the techniques, the styles, the functionalities, etc.

4 To those 44 towns is united to them many other where indications of paving with mosaic have not been documented, and will be necessary in the future to add other so many deposits in which the rest of pavements or tesserae evidence that at the time also counted on mosaics (Vargas Vázquez - López Monteagudo 2016; in print). The presence of tesserae in deposits still to excavate and documents by 
From all of the above, it follows that the research of the mosaics of Baetica shows a complex and interesting heritage that places the province as one of the largest number of Roman mosaics contributed so far. With a clear predominance of the geometric mosaic, especially in the Roman villas.

This circumstance of the presence of a greater number of geometric mosaics has nothing to do with chronological aspects or with a greater probability with economic aspects, since the pavements with figurative representations surely had to be more expensive than geometric ones. Although, that affirmation can not always be applied in a strict way in all of the cases. There it exists the possibility that some proprietors felt a major predilection for geometric mosaics, due to factors tied with trends and fashions imposed at certain moments, or simply a personal preference towards that decorative type. Proprietors who, at the same time preferred figurative elements over other supports such as sculptures or painting murals. A clear example of this could be the villa of El Ruedo (Almedinilla, Córdoba), in which all well-known mosaics are especially geometric, mosaics of great beauty, which in some cases exhibit excellent geometric compositions which don't need to envy the figurative representations (Vargas Vázquez 2016: 318-319).

In favour of the enhancement and value of geometry it is not necessary also to forget something extremely important like the complexity and the laboriousness of some compositions, as well as the excellent location that this matter reached in the old world, whose dominion was a faithful reflection of culture and wisdom (Vargas Vázquez 2016: 318). In addition to this, it is a subject of essential knowledge in important areas such as architecture, engineering, surveying, etc., whose compositions were applied to the aesthetic point of view, multiple supports and materials destined to embellish all types of buildings in public and private sectors, and other elements like clothes, weaves, ceramic, jewels ,arms, etc. In this way, mosaics, paintings, cornices, friezes, stuccos, reliefs, jewels, ceramics, etc., constituted elements susceptible to be decorated and embellished with simple and, sometimes, complex geometric designs. Geometry constitutes, in this sense a thematic presence within the Roman society, which we sometimes trivialize and consequently deny importance to that it had and also has nowadays (Vargas Vázquez 2016: 31).

It is also interesting to see how geometry sometimes forms an ideal element to frame the different scenes that are to be represented in the mosaic or, as Dra. López Monteagudo has pointed out, to compartmentalize and fragment a given scene or story (Fig. 1). In the case of Baetica, one of the most notorious cases, in which geometry interacts masterly with the figurative element, we find it in one of its main and most significant sites, Italica, with beautiful mosaics that show the interest of some owners by geometry, and in which it acquires a fully decisire paper.

Next onto the elaboration of the catalogue. It is essential to have a control of all the Baetica' pavements, the strength and perhaps more importantly, of our methodology and our work of investigation. This involves individualizing and analyzing, to draw and classify all present geometric compositions in the studied

archaeological prospections shows the possibility of the existence of mosaics in the same. Zones exist near present Écija and others located in surroundings of course under Guadalquivir, in areas near populations like Dark-brown of River or Palma del Río, among others, where they document an important number of deposits with presence of tesserae that can be demonstrating the existence of great towns, many of probably paved them with mosaics (it see in this sense the prospections realized by M. Ponsich: Ponsich 1974; 1979; 1987; 1991). 
Figure 1

The Mosaic of "the love of Zeus" in Italica (López Monteagudo Neira 2010: fig. 24).

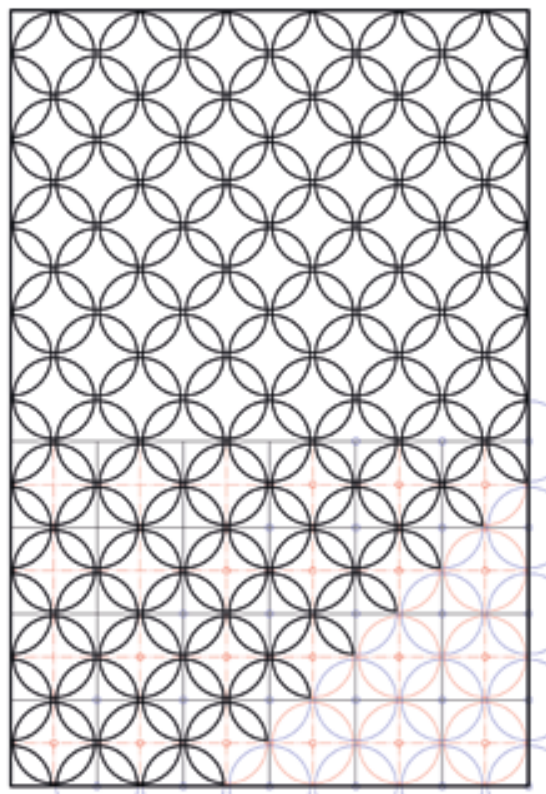

Figure 2

Design by Vargas Vázquez B17A.

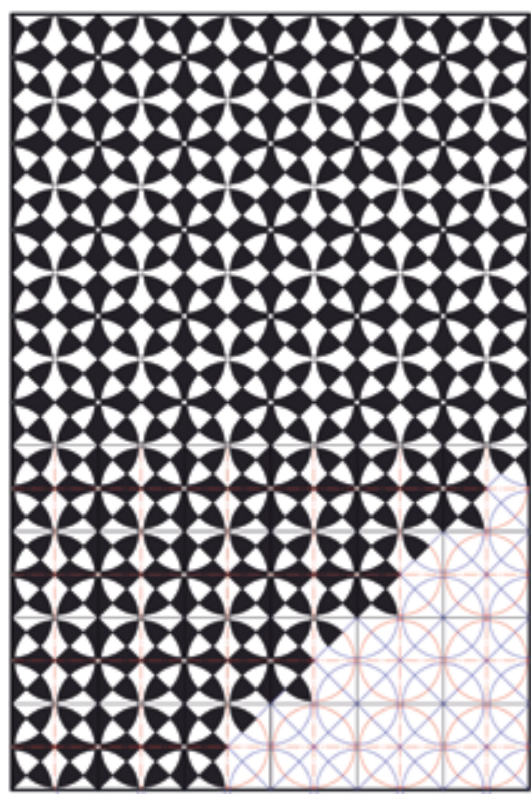

Figure 3

Design by Vargas Vázquez B18A.

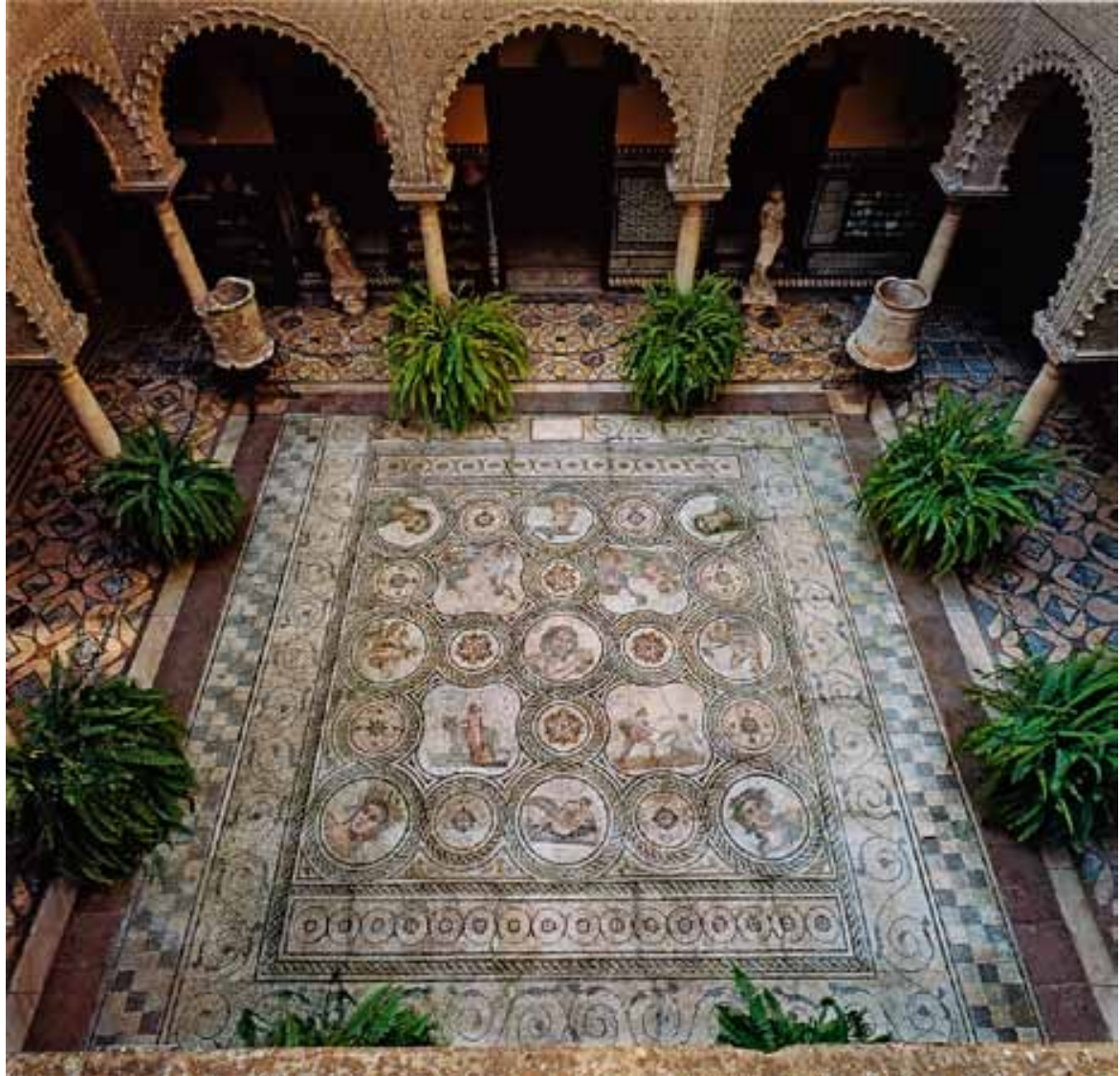

pavements, mainly those that approprietly compose and define their fields or carpets of mosaics, and also, all these compositions that are part of borders, constituting figures, simple or composed, which compose the auxiliary decoration of main and secondary spaces in the mosaics ${ }^{5}$.

Throughout the elaboration of our designs we try to build models, developing the drawings from zero and applying precise methods, sometimes simple, in agreement with the circumstances of the time. A method that is providing some interesting results that force us to think and to rethink each one of the models, drawing them all from base up. It is exactly this last act that has allowed us to discover something extremely important which is to verify some of them you need to follow rules very close to their elaboration, or better still, designs that at first do not own a similar appearance, share the same origin and/or initial base in its development. This happens for example with the composition of four-leafed designs (Fig. 2). These are present in a multitude of mosaics from Baetica and with our design of four-leafed flowers and crosses with lance form (Fig. 3), extracted from a mosaic in Écija. As it is possible to be verified, in spite of the aesthetic distance that exists between these models, both share a very similar base, arisen from a plot from tangent and drying circumferences. In the case of the second model, the difference with first settles down with the introduction of diagonals lines that cut the petals in two. With regards to colour, this element is essential to fill the model's content and to establish the differences clearly.

5 In parallel to the study of the geometric compositions that define the mosaics' fields, we are coming to analyze, to individualize, to classify and to draw all the geometric, simple or complex figures, that they comprise of decorative to help and/or secondary equipment of the mosaics, as well as the geometric compositions that shape their borders. 
Once drawings are created in the different designs, the following step of our work consists of classifying and grouping them from purely geometric criteria. In this sense, the units are grouped in a same family according to a same geometric base for their accomplishment or, simply, from the figure or more excellent geometric figures or with greater predominance in the same.

At the moment we have established 12 families of geometric designs (including the compositions with linear elements) from A to L, which pick up the compositions of interlaced ends or embroidery. Group B corresponds to the designs with circular elements, $\mathrm{C}$ to those in which the triangular elements predominate. Group D emphasizes the quadrangular elements, $\mathrm{F}$ the octagonal ones and $\mathrm{G}$ contains designs of crossings of scuta. Group $\mathrm{H}$ focuses on those which swastikas retain greater prominence, I contains compositions with dodecagons, J with stars with four ends and $\mathrm{K}$ with stars of rhombuses ${ }^{6}$.

Within the different conformed design families, some already existing which pick up a nourished and an ample number of compositions, like the ones that reunite the designs with circular or basic circular elements, or others which predominates the quadrangular base or the quadrilateral forms. Following these, although with obvious differences, are the composition groups with octagons, stars of rhombuses and four ends, such as swastikas and hexagonal shapes among others. Next to these, there are less numerous families which do not pick up a concrete model, due to its singularity and its own formal characteristics, as with the composition of interlaced ends (Fig. 4), or the one of crossings of scuta. In this last case there are two variants, one is defined with an end in curved stars (Fig. 5), and the other one with the straight ends (Fig. 6). In the case of Baetica, it is very peculiar to verify how, nowadays, all the pavements that show this design are under the modality of curved ends, documenting in mosaics of Córdoba, Écija, Antequera and Sevilla, which are different to other nearby zones such as Lusitania, in which the second variant abounds.

From the point of view of the scheme in the final configuration of the mosaics, in the Baetica we find practically all the modalities, emphasizing in the modular and/or continuous compositions, based on the repletion of a same figure or module (Fig. 2-6). At the same time, we find pavements formed by a centered plot as it shows, for example, in mosaic of the allegory from Écija (Fig. 7).

Sometimes, we find interrupted modular compositions by a large figure that acts as a decorative main field or emblem, as with the Triumph of Bacchus mosaic, carried by centaurs from the Plaza de Santiago of Écija (Fig. 8). The mixture of both types gives a result of mixed configurations that alternate the modular compositions or continuous and centered decorations (Figs. 8-9). Even though it can also be generated within a same mosaic with different centered compositions, or different modular designs, or the mixture between both modalities. These types of mosaics, are sometimes used to pave large spaces, like corridors and galleries, and to define rooms with paving, especially cubicula or triclinia. In the first case, they are those mosaics which reserve less important fragments to locate a bed; in the second, the mosaics are organized from a scheme like in $\mathrm{U}$ or $\mathrm{T}+\mathrm{U}$.

Within the mosaics organized into specific geometric patterns, we find those that show the geometric design in a clean, undecorated way (Fig. 10), recharged with geometric or vegetal auxiliary decorations (Fig. 11); or those where the game with colors defines the final result of the composition (Figs. 2-3). At the

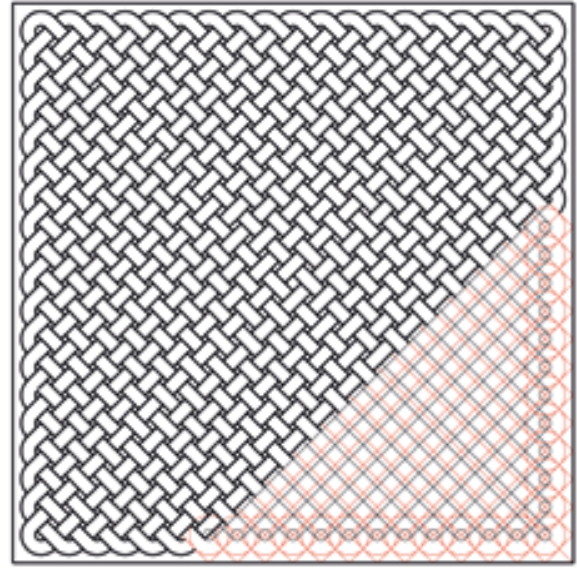

Figure 4 Design by Vargas Vázquez L1 .

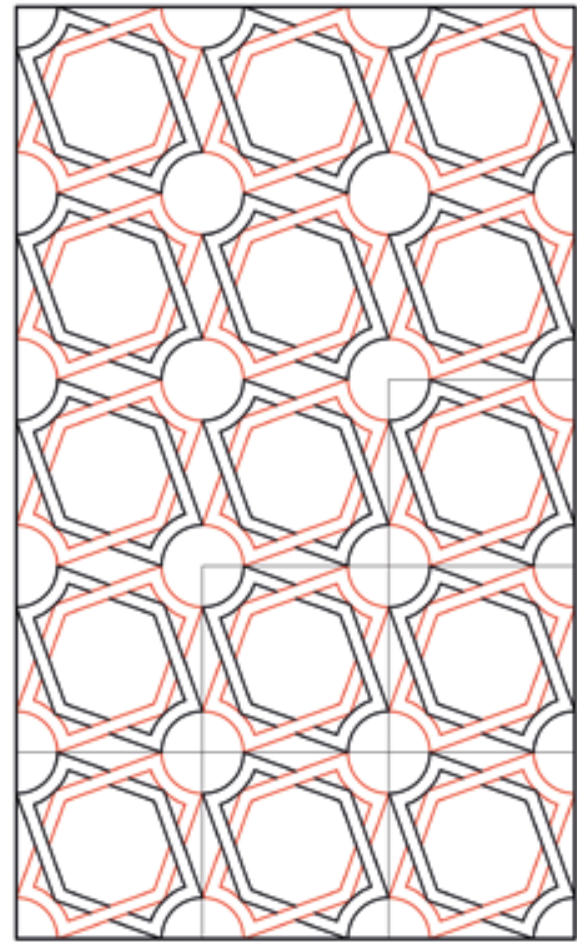

Figure 5 Design by Vargas Vázquez G2.

6 Part of the catalogue already made can be seen in Vargas Vázquez 2014, 2016. 


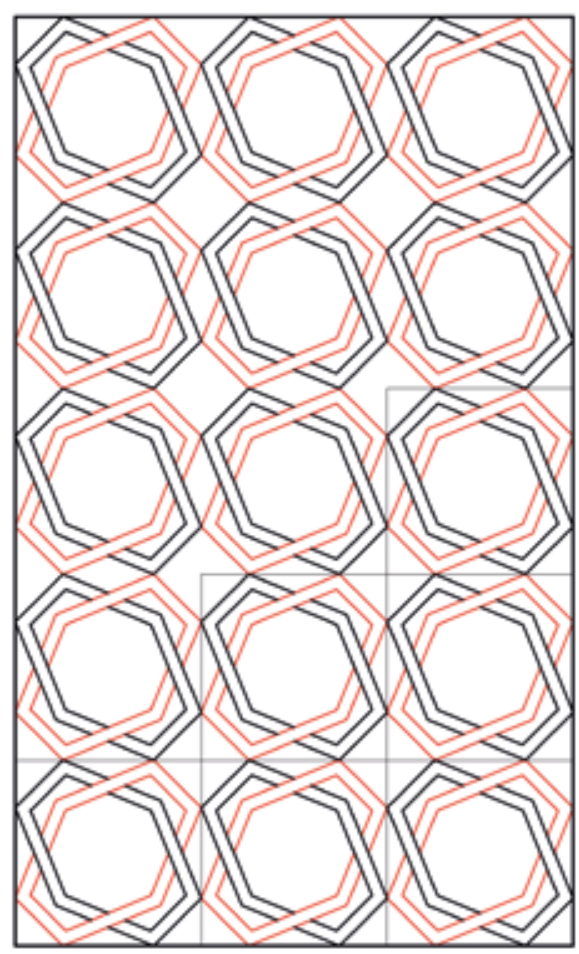

Figure 6

Design by Vargas Vázquez G1.

Figure 7 The mosaic of "the allegory" in Écija.
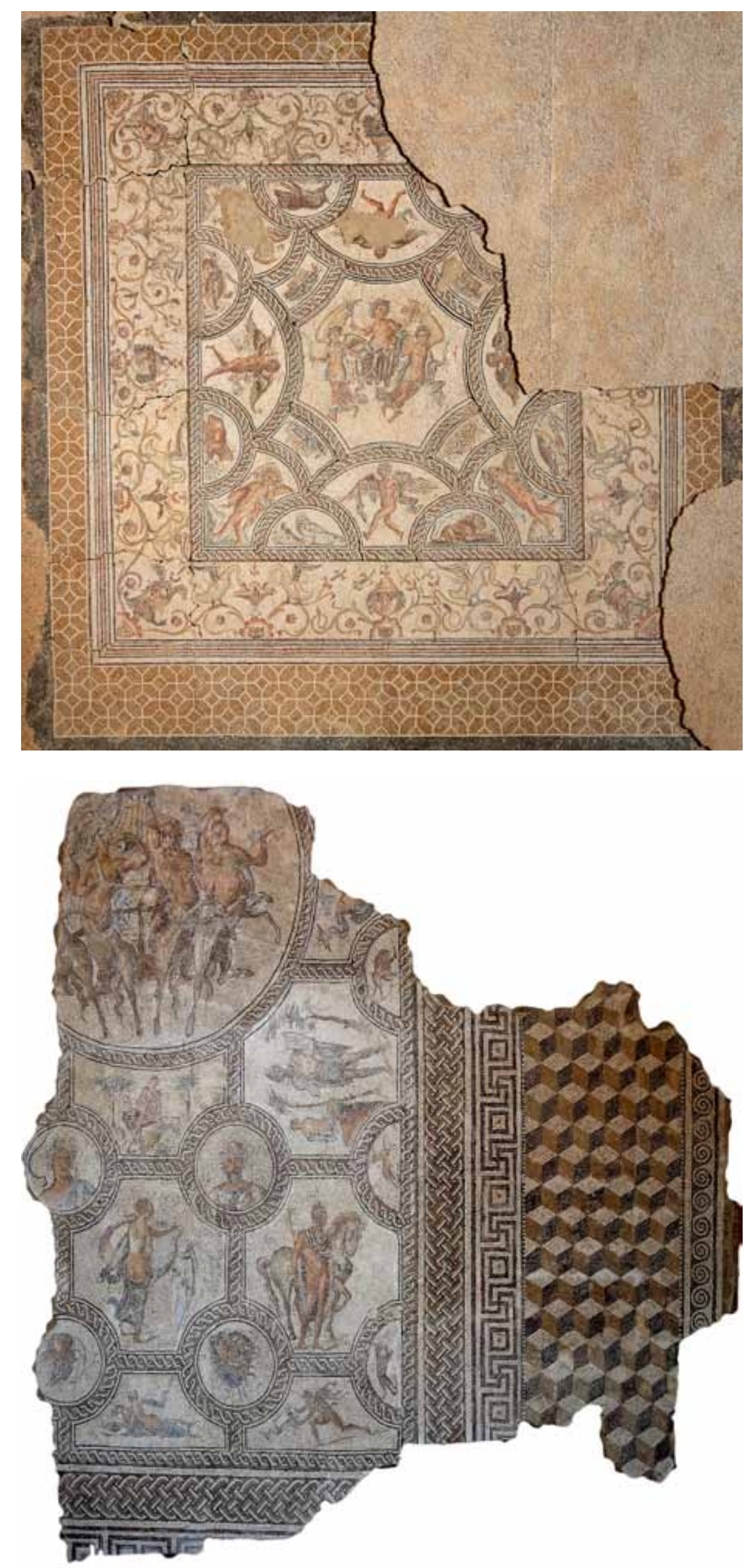


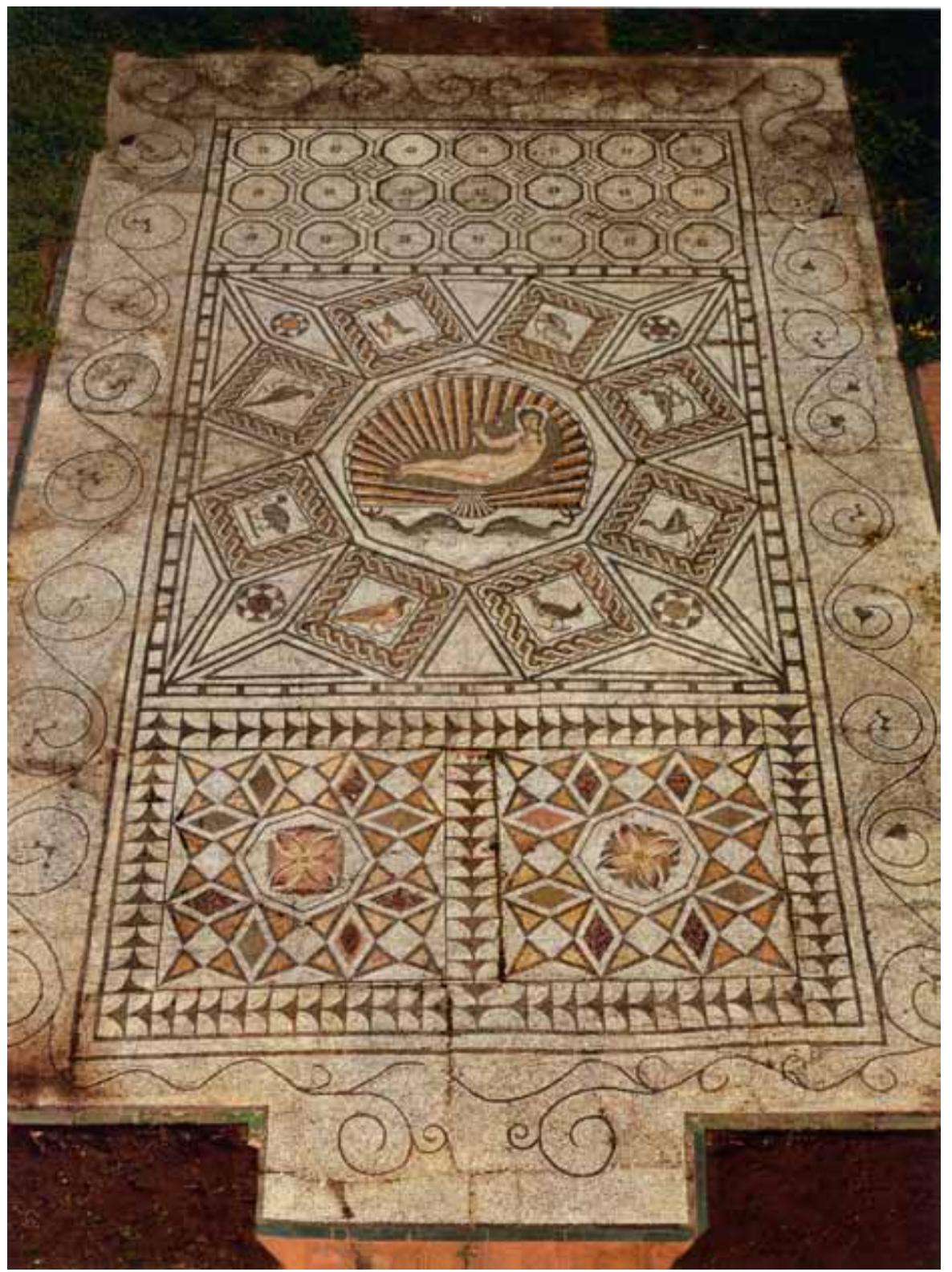

Figure 9

The mosaic of the Birth of Venus in Cártama (Cartama, Málaga), (López Monteagudo - Neira 2010: fig. 123).

same time, we find units where geometry becomes an ideal frame to distribute the figurative elements (Fig. 12, among others). The geometric compositions with vegetable shapes and other aesthetic resources go with models showing a greater baroque style and wealth, appellants in many areas of the Empire, like North Africa ${ }^{7}$. These are not very common in the Baetica, documented in very few units being located (some of the most significant in Italica).

In addition to the previous one, it is necessary to show that the use of geometry does not immediately end with the application of the established basic models. In the Roman Baetica, as in other many places of Roman world, we can find some articulated and diverse designs, which we find in our design Vargas-Vázquez E1 (Fig. 13), which in some places are developed in a simple way (Fig. 10), and in others they undergo a process of a very interesting baroque style, when recharging itself in a very special way with decorative elements (Figs. 11 and

7 Examples picked up in Germain 1973: 259-274; Balmelle et al. 1990; Ben Abed-Ben Khader et al. 2001; Ben Abed-Ben Kahder 2006; In addition to this, Ovadiah 1980. 
Figure 10

Geometric mosaic.

"Casa de los Pájaros" in Italica.
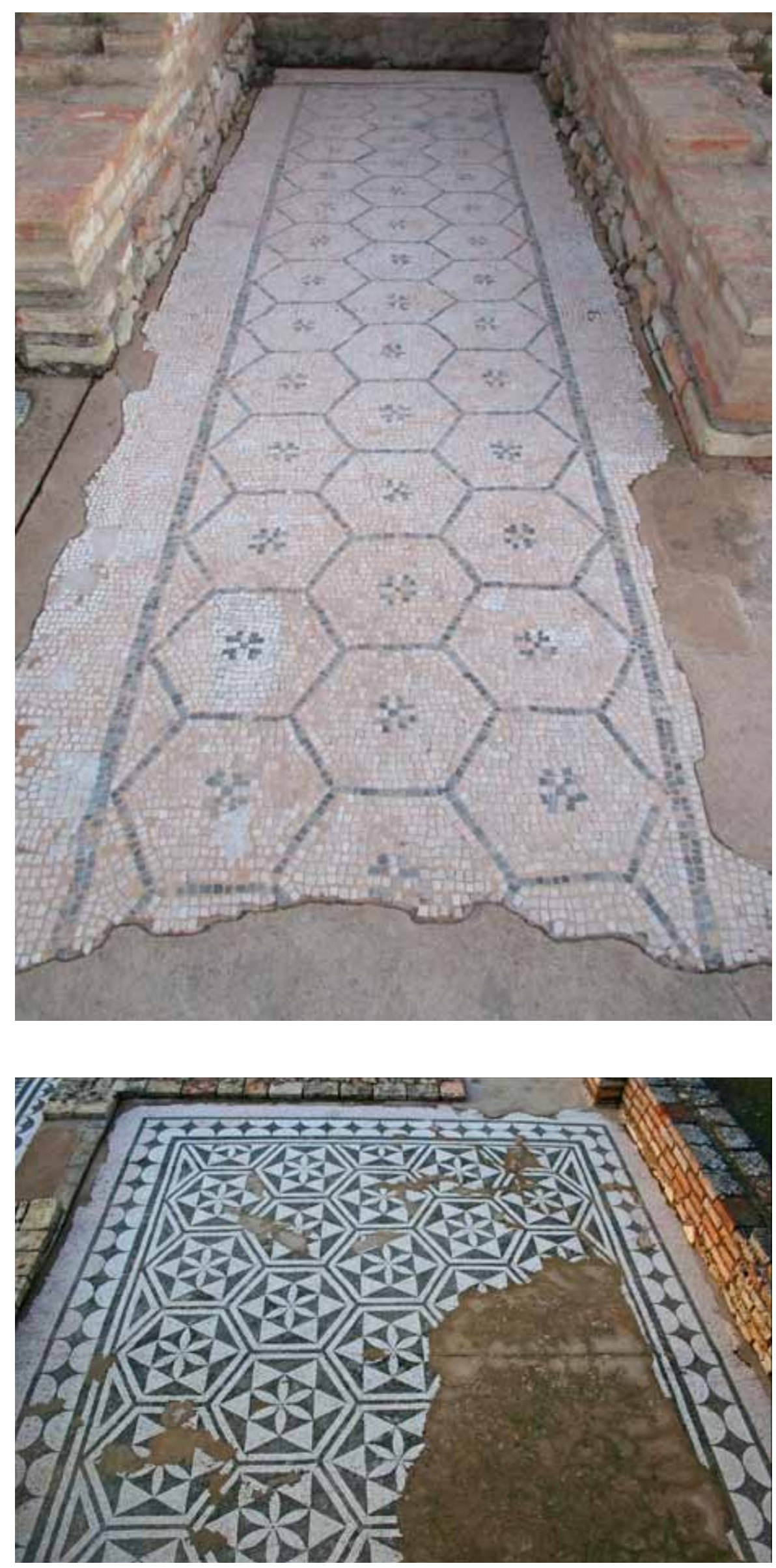

Figure 11

Geometric mosaic.

"Casa de Neptuno" in Italica. 

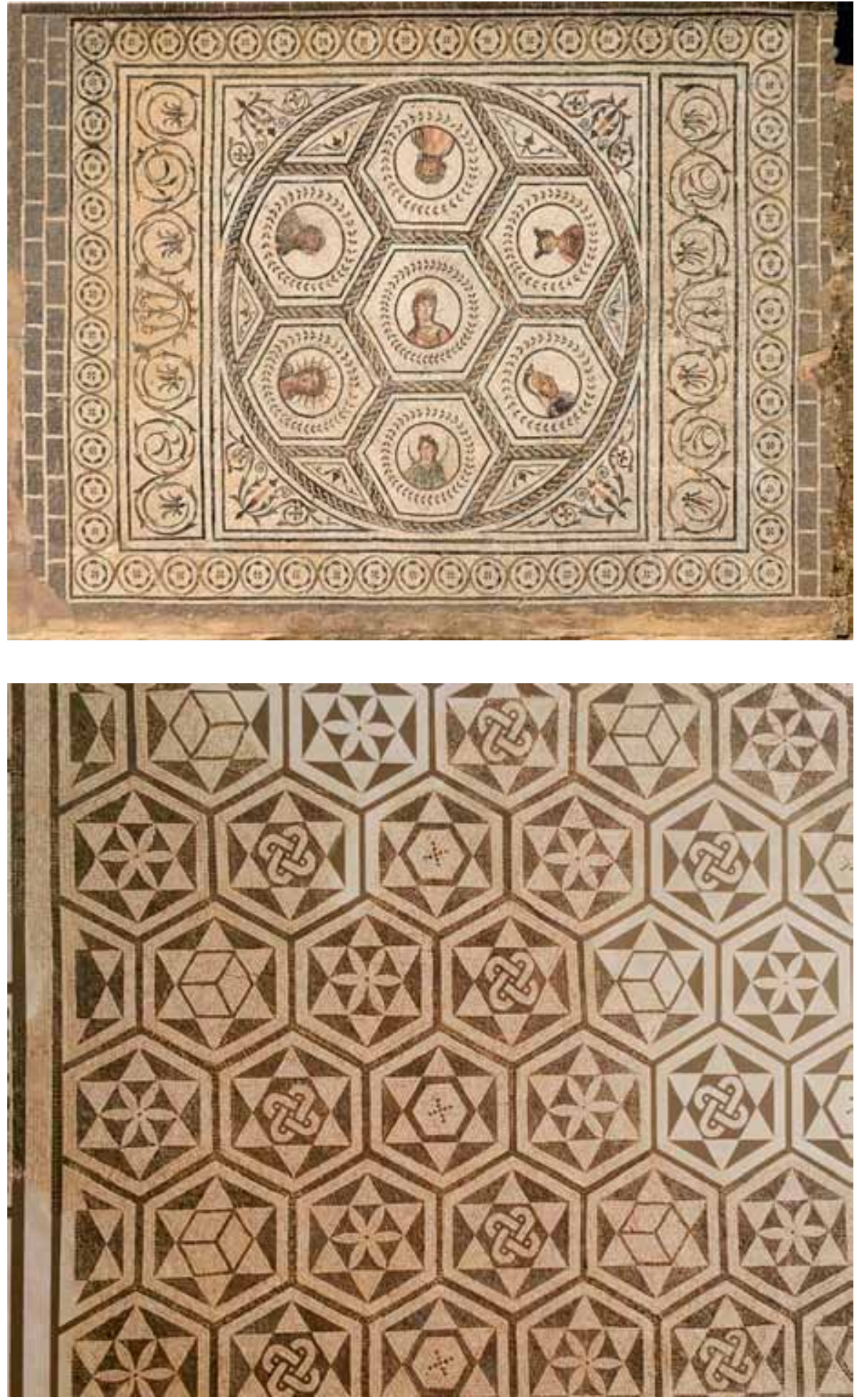

14). Another unit that previously reunites the set out characteristics is the mosaic of the Planetarium, which gives a turn to the composition of bee honeycomb (Fig. 13), and it enriches in a skillful way when it is framed in a great circle and it is recharged with representations of the planetary deities (Fig. 12). The previous examples from Italica could induce to think that the figurative element becomes to have a great prominence, whose consequences is that geometry is relegated to second place, acting as a simple and mere element of frames. However, the enormous presence of mosaics of this type as an important archaeological site as Italica questions this proposal. It comes to powerfully reinforce the idea that
Figure 12

Mosaic with representations of the planetary deities.

"Casa del Planetario" in Italica, (López Monteagudo - Neira 2010: fig. 205).

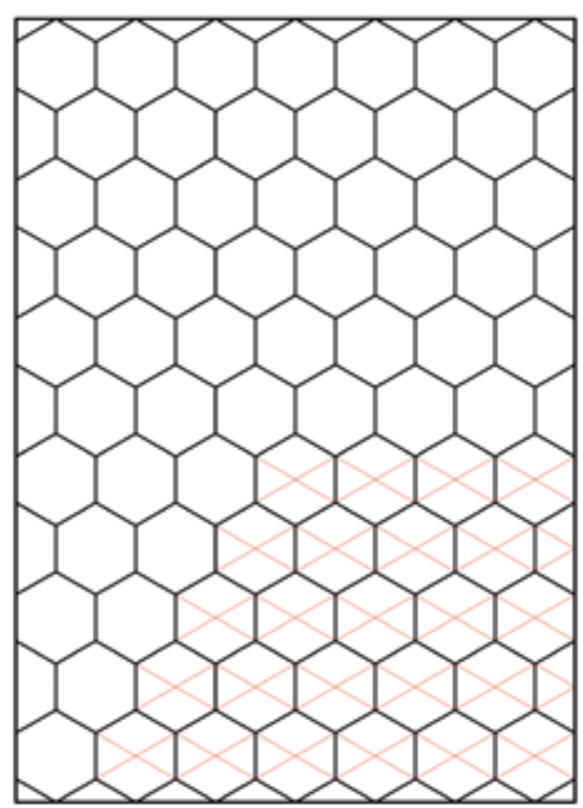

Figure 13

Design by Vargas Vázquez E1. 


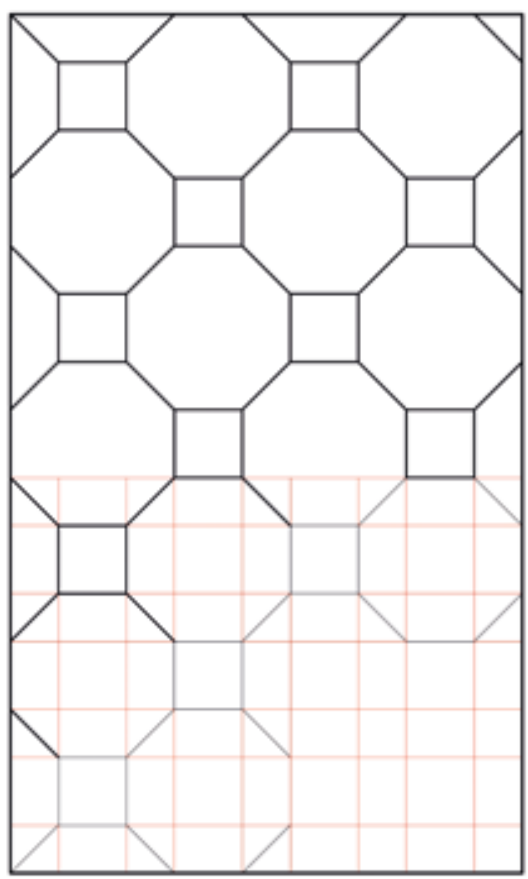

Figure 15

Design by Vargas Vázquez F1, straight version.

Figure 16

Design by Vargas Vázquez F5, straight version.

Figure 17

Design by Vargas Vázquez K2.

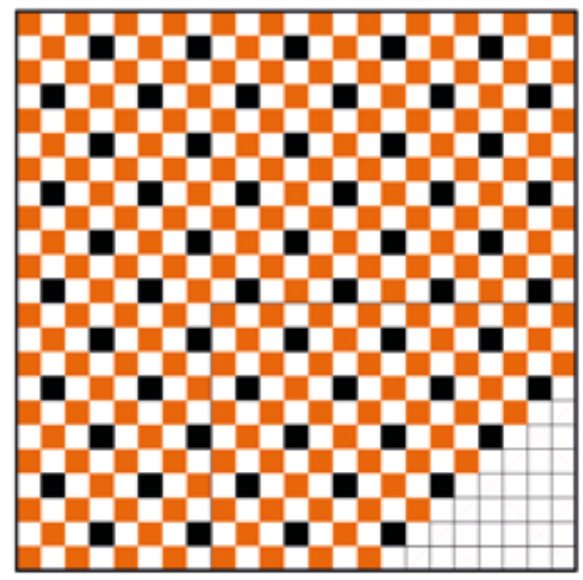

Figure 18

Design by Vargas Vázquez D7.
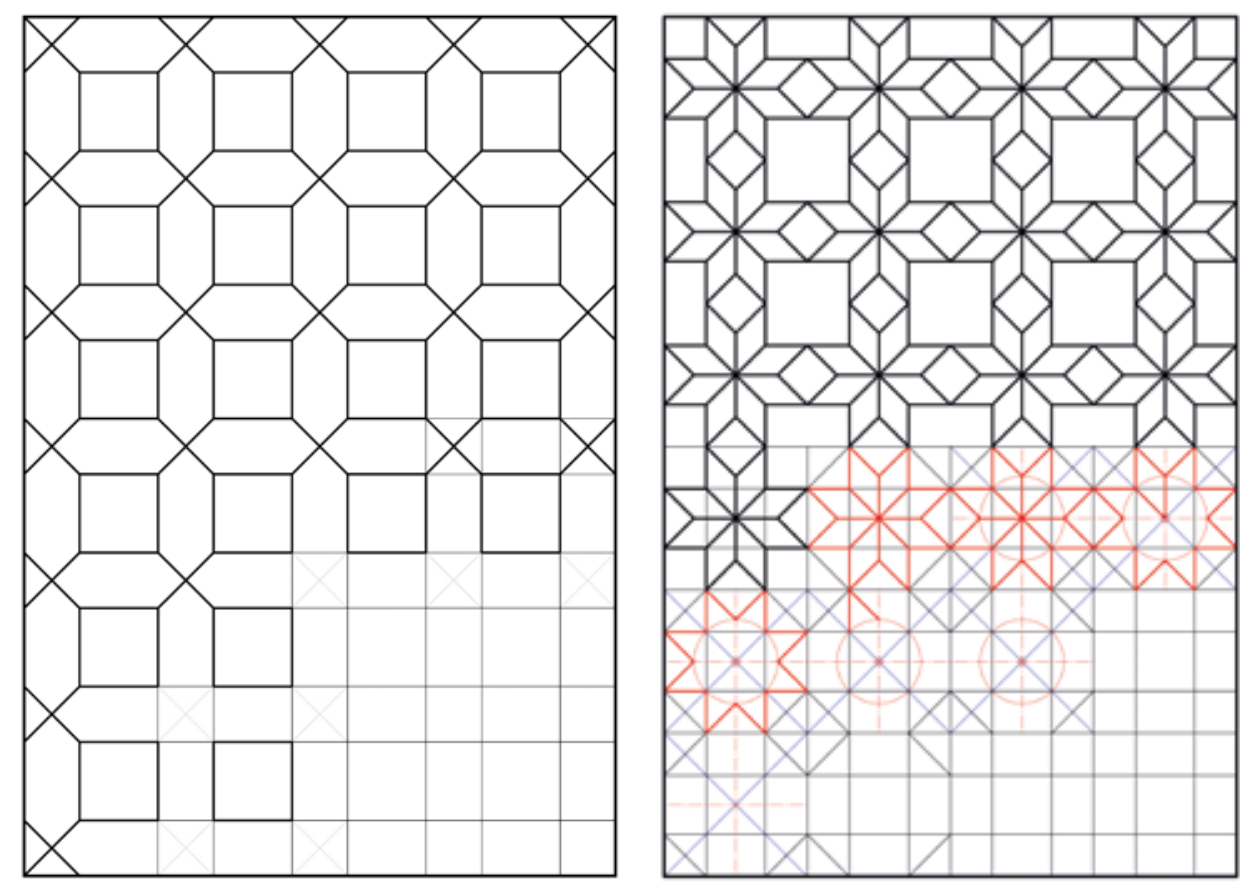

it is a trend and prevailing fashion, in which we have previously seen, that the geometry is a conjugated skillful way with which the figurative element gives a major relevance and meaning to the pavement. It could be said without any reservation regarding the majority of pavements in Italica. In addition, in other places within the Baetica geometry becomes essential and reaches a prominent place, denoting good taste and knowledge by the owners, at the same time as exigency, considering the good results and the correction that the majority of these units shows. This last characteristic saturates and puts in evidence the knowledge and good work of many Baetica' factories and the craftsmen, who work in particular in Italica, and in other areas from the Baetica too.

Concerning geometric designs used to compose the mosaics from the Baetica, the variety is enormous, and our work already includes more than 130 different compositions $^{8}$. The modular compositions are emphasized on the repetition of an identical figure, and within them, the most used in the Roman Baetica are those of four-leafs (Fig. 2), the honeycomb or tangent hexagonal composition of bee (Fig. 13), those of tangent octagons (Fig. 15) and tangent and drying octagons (Fig. 16), in their different variants, with or without swastikas, among others. The compositions articulated from stars of rhombuses are also popular in the Roman Baetica (Fig. 17), in their multiple variants.

Drawing in simple squares or checkerboard (Fig. 18), is also a highly demanded design in the Baetica, as well as the continuous decorations where the swastika is used to define them. This last element, the swastika, deserves a special mention in the mosaics of Baetica, being one of the elements more appellant in its pavements, when being presents like an isolated element, comprising of the border decoration in different versions, or when giving sense to the geometric designs that they compose the mosaics' fields, as in the previous case comprising

8 To these examples is necessary to add a great number of geometric figures, simple and complex, used as elements of auxiliary or secondary decoration, and an important border repertoire of geometric compositions. All of which comes to demonstrate that geometry is not a secondary nor banal element, on the contrary, it is supposed an element of first order that denotes wealth and provides to the mosaic and added value. 

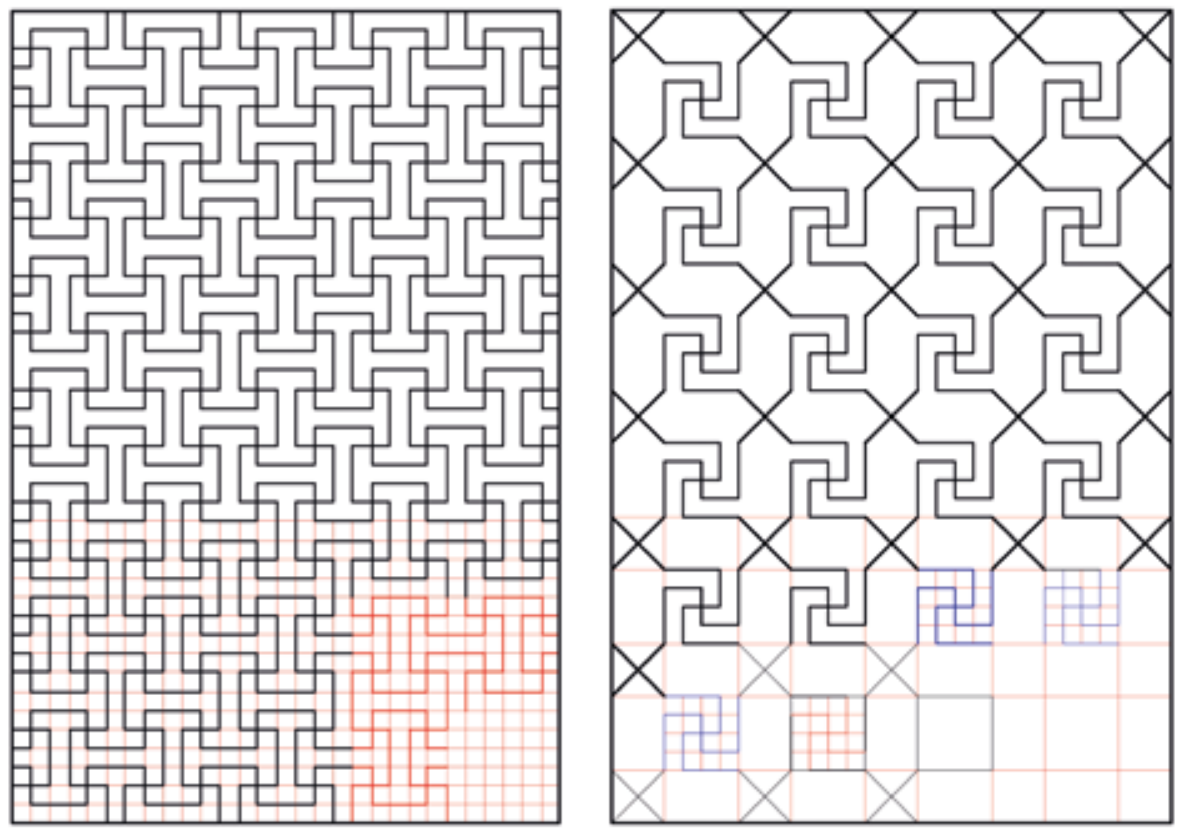

Figure 19

Design by Vargas Vázquez H5 (example of composition with swastikas).

Figure 20

Design by Vargas Vázquez F6, straight version.

of different variants. In this last case, we can find it acting as a main element (Fig. 19), or introducing itself in other models to enrich it more (Fig. 20). Like the swastika other figures like buckets, peltae, scaless and the salomon knot, among others, constitute common figures in the Baetica' mosaics. We find them to comprise of the auxiliary decoration, composing borders or the own mosaics' carpets.

The four-ends star composition, in its different variants, is also documented widely in mosaics of the Roman Baetica, as well as the eight-ends star. These are formed by two squares interlaced and turned $45^{\circ}$ one with respect to the other. This last figure we can see is again isolated, comprising of the auxiliary decoration, in a centered or modular composition. One of the deposits in which it is most used is Italica.

Within the Roman Baetica we also find singular and very interesting compositions and, as with the mosaics of Martos, with a design of garlands and octagons that, in spite of its bad state of conservation denotes an elegant and

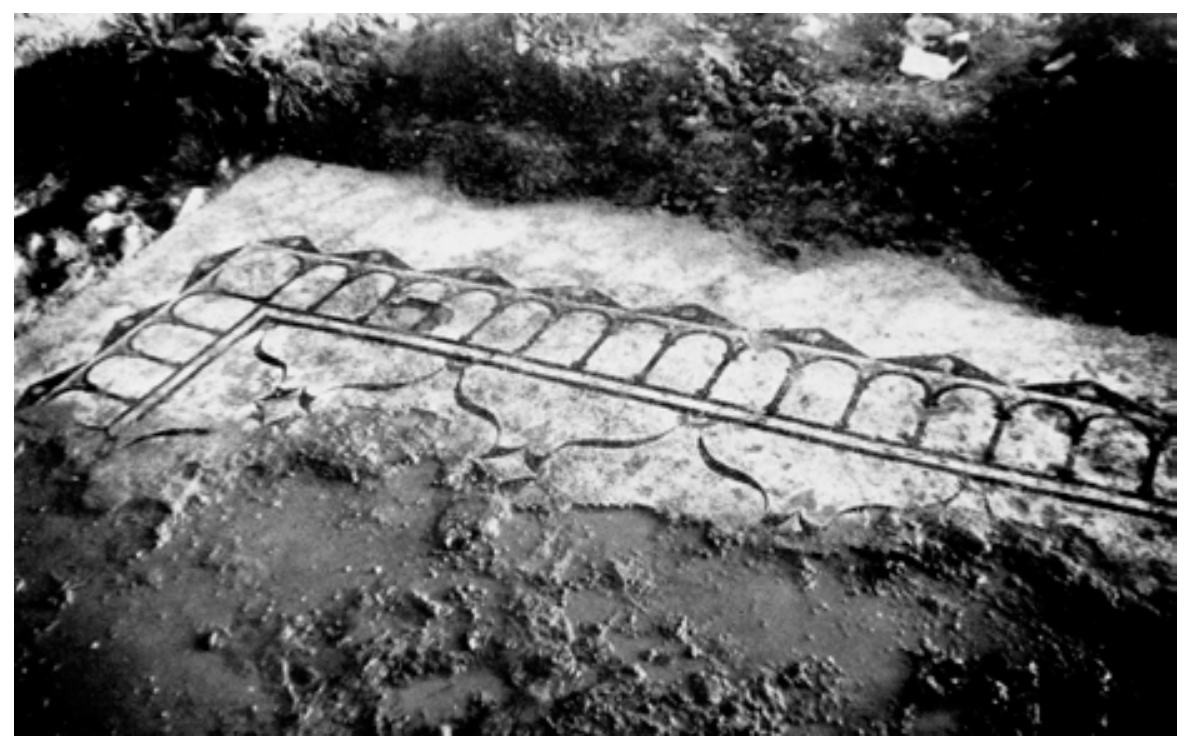




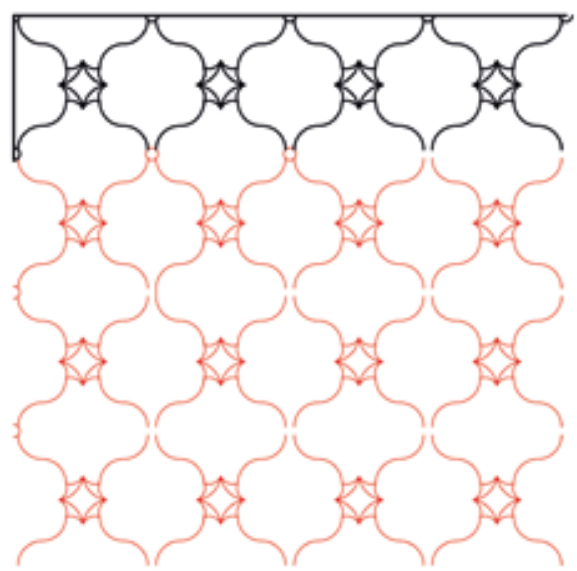

Figure 22

Design by Vargas Vázquez B11.

Figure 23

Geometric mosaic. Roman villa of "El Ruedo" (Almedinilla, Córdoba). fine finish (Figs. 21-22); or like that, it shows in the mosaic of the Allegory of Écija (Fig. 7). Although, we don't take into account that this singularity can be temporary and it can change at any time, as happened with the composition of crossings of scuta (Fig. 5 and 6), documented before in a mosaic of Córdoba and that in the last years, this number has increased with two units in Villa de la Estación of Antequera, other two in Écija and one more in Sevilla.

The compositions are frequently centered, whose units are very well-known, for example one of central octagon framed by squared (Fig. 23) or rectangular (Figs. 24-25) geometric designs highly demanded in Baetica (López Monteagudo - Neira 2010: 56-58; Vargas Vázquez - López Monteagudo 2014: 134), as in the villa Casa de Mitra in Cabra, Córdoba, changes the octagon by the hexagon in a modular composition of a greater interest (Fig. 26). Hexagonal mosaics, instead of octagon, in modular composition are also documented in Italica, and in compositions centered in the mosaic of the Medusa of the Casa del Planetario (Fig. 27).

Centered and very interesting compositions are also documented in the villa of El Ruedo (Vargas Vázquez 2016: 111-116) and the mosaic of the paves room 5 in the villa of the Torre de Benagalbón (Rincón de la Victoria, Malaga) (Mañas - Vargas Vázquez 2010: 331-333) has a great beauty, developed with great success (Fig. 25).

The rosette of curvilinear triangles also finds certain acceptance in the Roman Baetica (Fig. 28), which are documented at present into eight mosaics. In the modality in black and white we have found it in an Italica mosaic, three in Carmona, one in Alcolea del Río, another one in Niebla and one more in Puerto

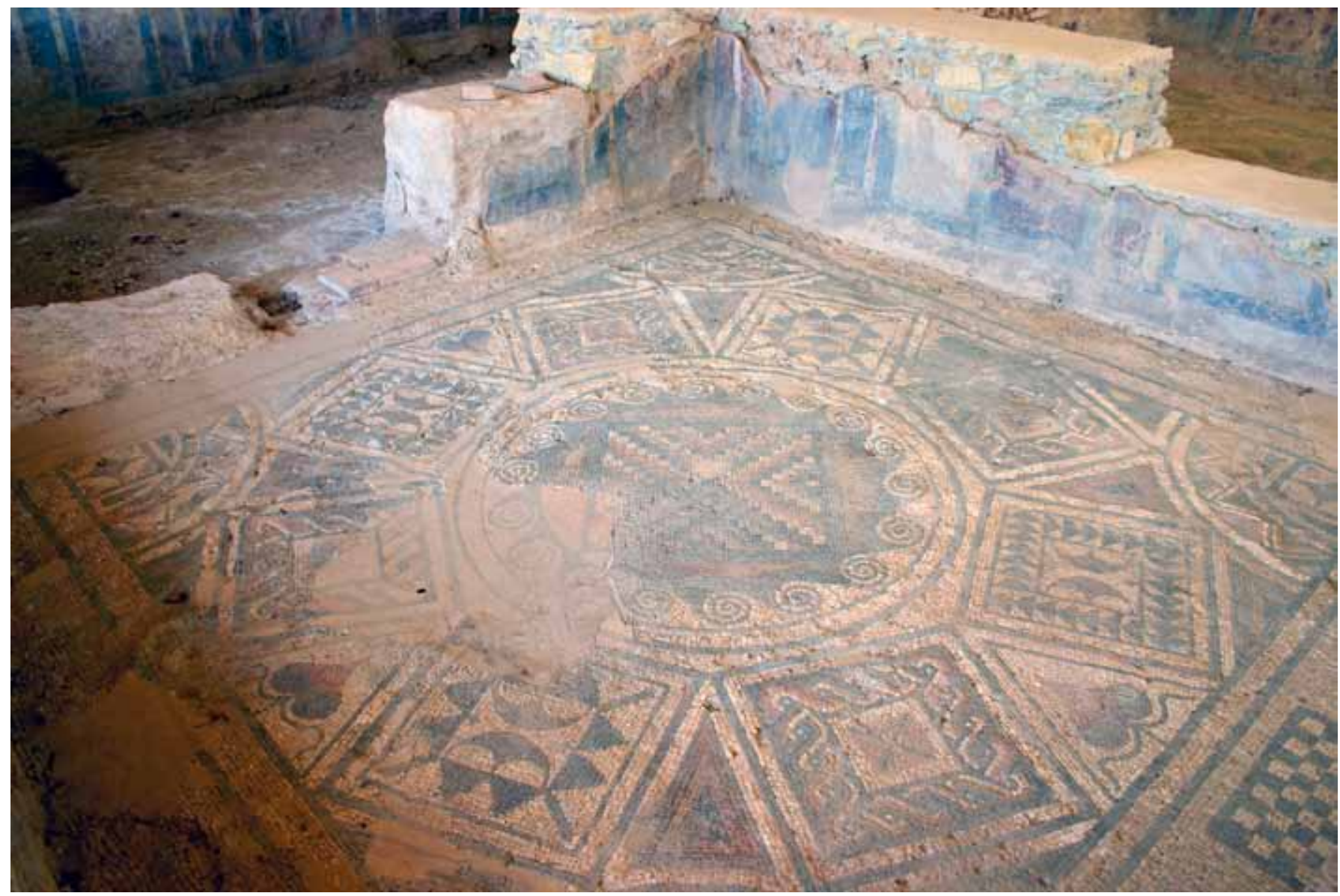



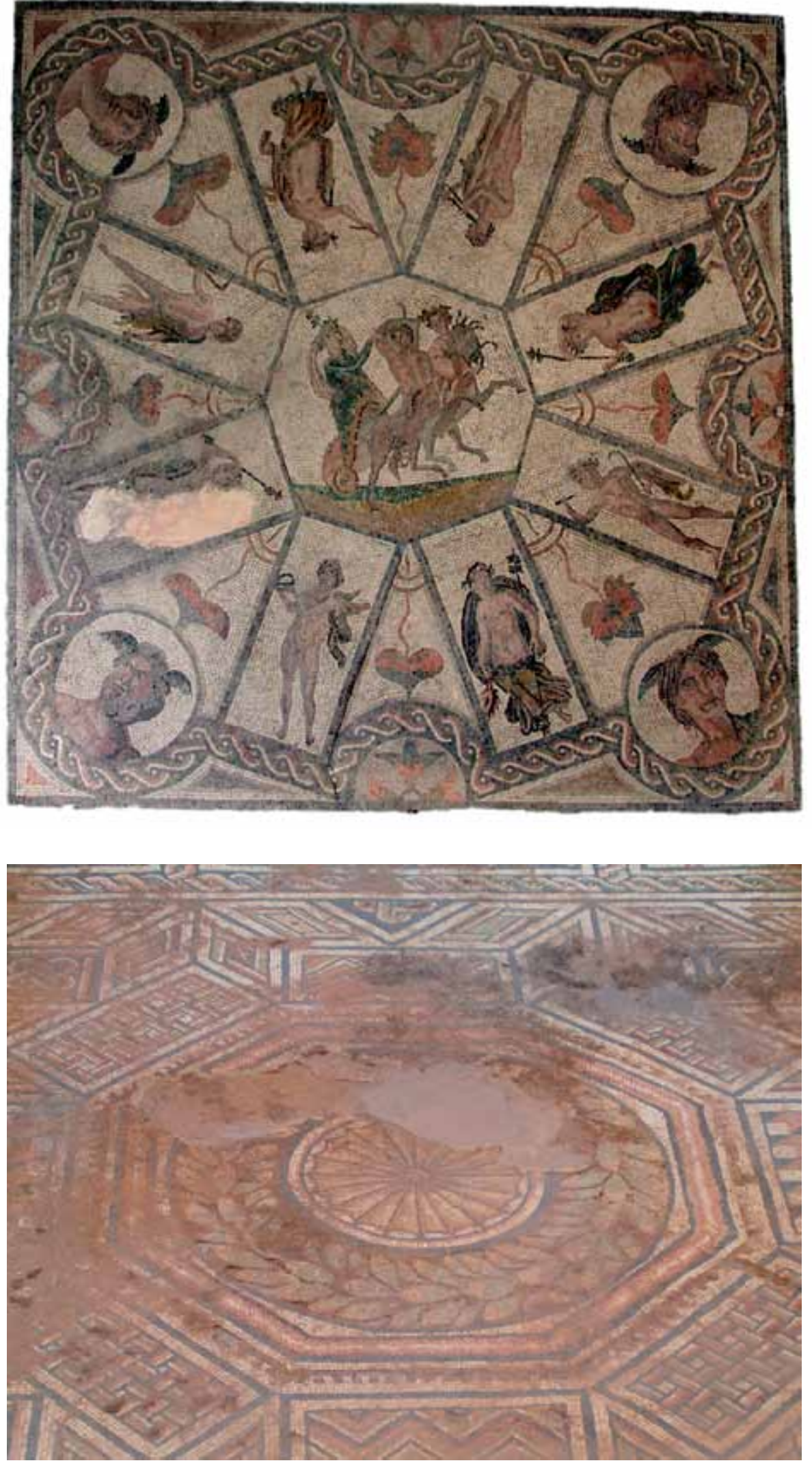

Real. The polychrome rosette is documented in Écija and in the Roman villa of Herrera (Vargas Vázquez 2015: 585-596). The rosette of scales (Fig. 29), although to a lesser extent, it is also documented in Baetica, a mosaic of the "Plaza de la Encarnación" of Sevilla (López Monteagudo 2016: 40) and another one in
Figure 24

Mosaic of "the Triumph of Bacchus". Roman villa of "La Valenzoneja" (Alcolea, Córdoba), (Museo Arqueológico de Córdoba).

Figure 25

Geometric mosaic. Roman villa of the "Torre de Benagalbón"

(Rincón de la Victoria, Málaga), (photo courtesy Salado Escaño, J. B.). 


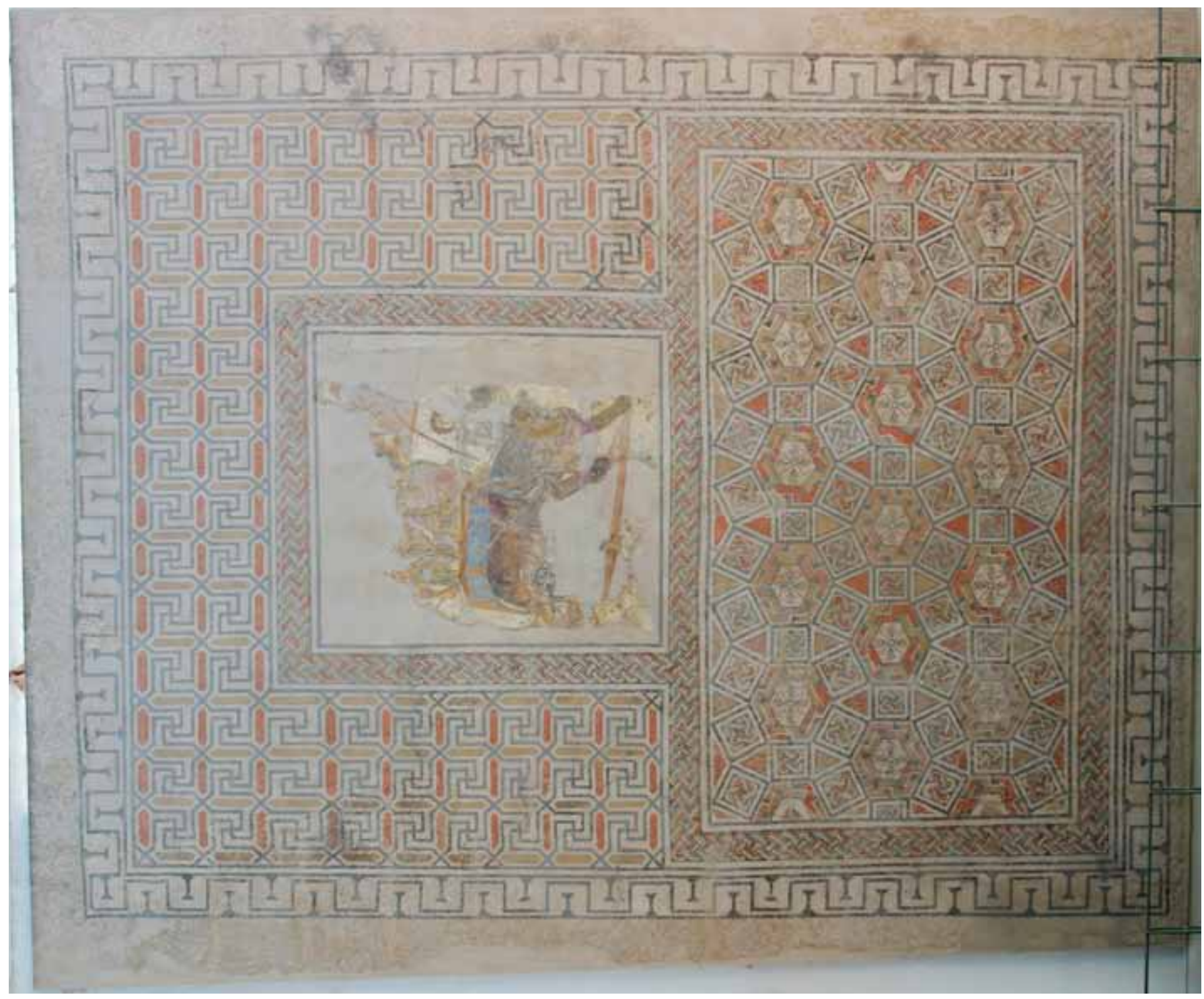

Figure 26

Mosaic of "the Triumph of Bacchus". Roman villa of the "Casa de Mitra" (Cabra, Córdoba). a Roman Villa El Arca, in Castro del Río, Córdoba (Bretones - Vargas Vázquez 2008: 224-227; Vargas Vázquez 2016: 135-135).

If as we have just seen, the mosaics of Baetica exhibit an ample and rich range of geometric designs, this same wealth is documented in its borders, which exhibit an ample range of compositions, with decorative interlaced ends being most common, in its different versions, for example like those of ogive, those of peltae, those of rhombuses with peltae faced two of its vertices, characterize them the most. Of those decorated with lines of contiguous triangles, those of swastikas, in their different variants, etc. Next to them, the border of arcs or arcade requires special attention, which it is documented in multitude of sites, Italica, Córdoba, Écija and in the Roman villas of El Arca, El Ruedo, Torre de Benagalbón, El Alcaparral and Martos, among others.

Speaking of chronology does not have sense in this work, but now we want to express some considerations that have to do with the subjectivity, pointing many of the granted chronologies in the Baetica mosaics, especially those which have settled down following a stylistic method, from the search of parallels whose dating have not been contrast neither are always offered as trustworthy or accurate data. In addition, the great problem considers when the pavements from 


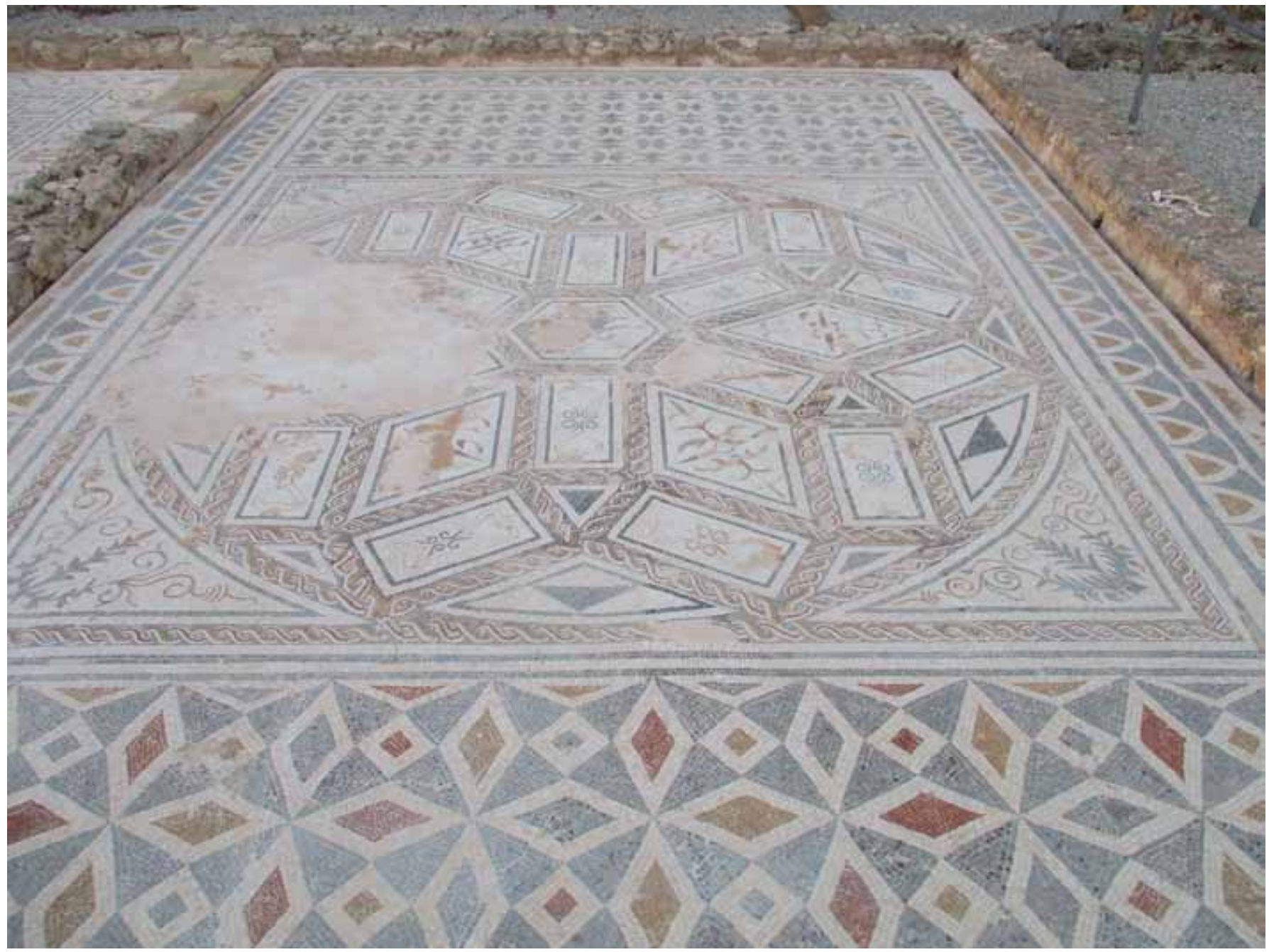

geometric elements and their compositions are used to date, which doesn't allow us to obtain accurate data.

Our study has allowed us to verify the enormous difficulties involved in the establishment of chronologies from geometric designs. The ample chronological axis where the majority of the models move, some widely popularized as the design of the four-petals, or a nest of bees or those of swastikas, among others. As well as this the difficulty to establish while concrete sprouting from a determined model, do, against the generalized practice beginning in not few occasions, which the majority of them do not work like chronological markers. Something similar happens with the chromaticism, which generally cannot be used like chronological marker.

The proprietors of the Baetica demonstrate a continuous and prolonged use of the mosaic as the ideal decorative element to pave the majority of their appraised rooms and spaces. The mosaic of opus signinum with incrustations of tesserae, present at the first moments of Baetica, until the middle of first century AC, take steps towards the traditional tessellations, which as we have seen include a great decorative and chromatic variety. This last element, the color, does not have to be taken at any moment as a chronological marker, since the mosaic in black and white, which was in fashion in the second half of the first century B.C. and the beginning of first century AC, especially during the Augusto's age, is also going to exceed those chronological limits in other zones of the Roman world
Figure 27

Mosaic of the Medusa. "Casa del Planetario" in Italica.

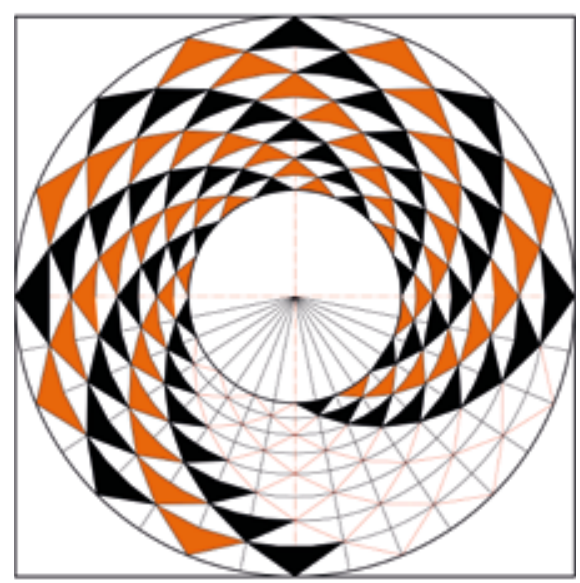

Figure 28 Design by Vargas Vázquez C2 


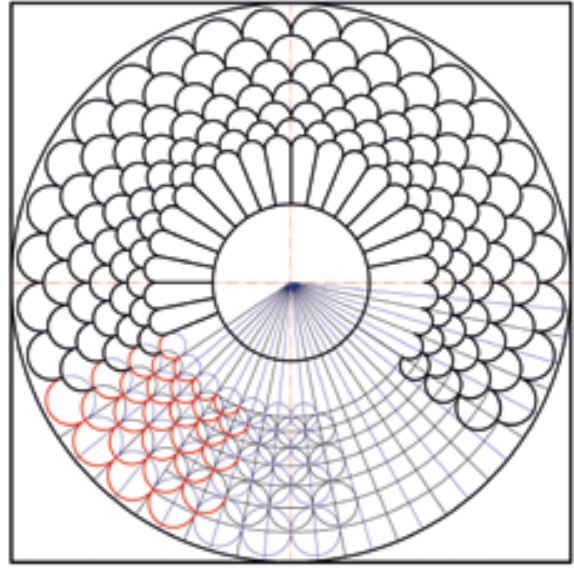

Figure 29

Design by Vargas Vázquez B14. and in Hispania, as it happens for example in Italica, which are documented in the second century. In the villa of La Estación, we found mosaics in black and white which were dated from the third century, or in the villa of Fuente Álamo, in which they are documented still more at delayed moments. It is very significant, however, the villa of Río Verde in Marbella, whose mosaics could adjust perfectly to those early dates around first middle of first century, even though has been dated later (Mondelo Pardo 1982-83, 173-190; Mondelo Pardo 1984-85: 121-130).

Up to here, the lack of space does not allow us to enter in major depths, as we only wanted to offer some general brush-strokes of our research, whose advances will be offered in future works, and to give a general vision of the importance of the mosaics from the Baetica, and within this one of the geometric mosaics. Pavements in which their rich geometric forms also emphasize their rich figurative and floral representation, reflect some tastes and determined fashions, and show that this type of pavement found a great acceptance in the Roman Baetica from very early on, being an article very consolidated and demanded within the urban scope but also in the countryside, where many of the owners chose them to pave their villas.

From this work, we have to emphasize on the importance of geometry within the Baetica mosaics, because of the enormous range of forms and geometric designs that they exhibit, and its own particularities, generally show an unquestionable and very present reality in Roman mosaics, related to their creativity, the singularity and the originality that their geometric designs denote and declare. A clearly contrasting reality through its geometric models and compositions, result, in many cases, in an intense and deepening revision in the geometric forms, basic and composed, and in their color (Vargas Vázquez 2009: 199-225; Vargas Vázquez 2016: 275).

\section{Bibliography - Kaynaklar}

Balmelle et al. $1990 \quad$ C. Balmelle et al., Xenia, Recherches Franco-Tunisiennes sur la mosaïque de l'Afrique Antique-I. Collection de L'École Française de Rome 125, Roma.

Ben Abed-Ben Kahder et al. 2001

A. Ben Abed-Ben Kahder et al. Trames géométriques végétalisées. Recherches Franco-Tunisiennes sur la mosaïque de l'Afrique Antique-II. Collection de L'École Française de Rome 288.

Ben Abed-Ben Kahder 2006 A. Ben Abed-Ben Kahder, Tunisian Mosaics, Treasures from roman Africa, Singapore, Getty Publications. Bretones - Vargas Vázquez 2008

J. Bretones Borrego - S. Vargas Vázquez, "La villa romana "El Arca” (Castro del Río, Córdoba)”, Romula 7, 209-248.

Germain 1973

S. Germain, "Remarques sur des mosaïques de style fleuri de Timgad et d'Hippone”, AntAfr VII, 259-274.

López Monteagudo 1998

G. López Monteagudo, "Producción y comercio del aceite en los mosaicos romanos", L'Africa Romana XII, 359-376.

López Monteagudo 2007 G. López Monteagudo, "El aceite en el arte antiguo", J. M. Blázquez - J. Remesal (eds.), Estudios sobre El Monte Testaccio (Roma) IV, Colección Instrumenta 24, Barcelona, Universitat de Barcelona, 433-520.

López Monteagudo 2016 G. López Monteagudo, Los mosaicos de la Plaza de la Encarnación, Roma en Sevilla, Sevilla, Ayuntamiento de Sevilla (ICAS).

López Monteagudo - Neira 2010

G. López Monteagudo - L. Neira, "Mosaico", P. León (coord.), Arte Romano de la Bética III, Mosaico, Pintura, Manufacturas, Sevilla, Fundación Focus-Abengoa, 17-189.

Mañas - Vargas Vázquez 2010 I. Mañas Romero - Sebastián Vargas Vázquez, "Nuevos mosaicos hallados en Málaga: las villas de la Estación y de la Torre de Benagalbón”, Mainake XXIX, 315-338. 
Mondelo Pardo 1982-83

Mondelo 1984-85

Ovadiah 1980

Ponsich 1974

Ponsich 1979

Ponsich 1987

Ponsich 1991

Romero Pérez - Vargas Vázquez 2012

M. Romero Pérez - S. Vargas Vázquez, "Mosaic workshop located in the Station Villa of Antequera, Málaga (Spain)", $11^{\text {th }}$ International Colloquium on Ancient Mosaics, October $16^{\text {th }}-20^{\text {th }}, 2009$, Bursa Turkey, 823-828.

Vargas Vázquez 2009

Vargas Vázquez 2014

Vargas Vázquez 2015

Vargas Vázquez 2016

S. Vargas Vázquez, "Jugando con las imágenes: El juego de la geometría en la musivaria romana”, Romula 8 , 199-225.

S. Vargas Vázquez, Diseños geométricos en los mosaicos de Écija (Sevilla). Archaeopress, BAR International Series 2654, Oxford.

S. Vargas Vázquez, "La roseta de triángulos en Andalucía”, J. García - I. Mañas - F. Salcedo, (eds.), Navigare necesse est. Estudio en homenaje a José María Luzón Nogué. Madrid: Universidad Complutense de Madrid, 585-596.

S. Vargas Vázquez, Diseños geométricos en los mosaicos del Conventus Astigitanus, Archaeopress, Roman Archaeology 13, Oxford.

Vargas Vázquez - López Monteagudo 2014

S. Vargas Vázquez - G. López Monteagudo, "Talleres musivos hispanorromanos. Formas de producción y áreas de dispersión” M. Bustamante - D. Bernal, (eds.) Artífices idóneos. Artesanos, talleres y manufacturas en Hispania, Anejos de AESPA LXXI. Mérida, CSIC, 127-142.

Vargas Vázquez - López Monteagudo in print

S. Vargas Vázquez - G. López Monteagudo, “Decoración musiva”, R. Hidalgo, Las villas romanas de la Bética, Sevilla, Editorial Universidad de Sevilla, 419-441. 